\title{
The Effect of Penicillamine on Serum Digoxin Levels
}

\author{
Bahram Moezzi*, Ph. D., Vahab Fatourechi*, M.D., \\ F.R.G.P. (C)., F.A.C.P., Roholah KHozarN*, M.D., \\ and Bahram Eslami**, M.D., F.A.C.C.
}

\section{SUMMARY}

The effect of $1 \mathrm{Gm}$ of penicillamine (pen) on serum digoxin levels (SDLs) of 3 groups of patients (Pts) on maintenance digoxin therapy was studied. Each group served as its own control. Group I (10 pts) had serum digoxin measurements (SDMs) 2, 4, and 6 hours (hrs) after receiving their daily oral doses of digoxin. The next day SDMs were made similarly following $1 \mathrm{Gm}$ of pen $2 \mathrm{hrs}$ after administration of digoxin. In all pts the SDLs were significantly lower 2, 4, and $6 \mathrm{hrs}$ after receiving pen $(1.86 \pm 0.25$ VS $1.62 \pm 0.22,1.80 \pm 0.17$ VS $1.44 \pm 0.26,1.87 \pm 0.27$ VS $1.14 \pm 0.24 \mathrm{ng} / \mathrm{ml}$, mean $\pm S D$ with respective $\mathrm{p}$ values $<0.025,<0.005$ and $<0.001$ ).

In order to exclude the interference of pen on digoxin absorption, Group II (13 pts) had SDMs 22 hrs after their last oral doses of digoxin before and $6 \mathrm{hrs}$ after receiving $1 \mathrm{Gm}$ of pen. In this group SDLs were also significantly reduced $(1.50 \pm 0.48$ VS $1.16 \pm 0.51 \mathrm{ng} / \mathrm{ml}$, mean $\pm \mathrm{SD}$, $\mathrm{p}<0.05$ ).

Group III (10 pts) received maintenance intravenous digoxin for 5 days prior to SDM. In this group also marked reduction of SDM was observed 4 and 6 hrs following $1 \mathrm{Gm}$ of pen $(1.36 \pm 0.50$ VS $1.04 \pm 0.40$, $1.46 \pm 0.69$ VS $0.50 \pm 0.64 \mathrm{ng} / \mathrm{ml}$, mean $\pm \mathrm{SD}$ with $\mathrm{p}$ values of $<0.001$ and $<0.005$, respectively). It can be concluded that oral penicillamine reduces SDL significantly in digitalized pts irrespective of the route of digoxin administration and may be of significant value in management of digitalis toxicity.

\section{Additional Indexing Words:}

Serum digoxin level Digitalis intoxication Serum digoxin measurement Penicillamine

\footnotetext{
From the Research Department* and Department of Adult Cardiology**, Queen Pahlavi Cardiovascular Medical Center, Teheran, Iran.

Supported by the research fund of the Queen Pahlavi Cardiovascular Medical Center.

Reprint requests to: V. Fatourechi, M. D., Research Department, Queen Pahlavi Cardiovascular Medical Center, Shahanshahi Park, Pahlavi Ave, P.O. Box 33-423 Shemiran, Teheran, Iran.

Received for publication October 25, 1977, revision accepted March 11, 1978.
} 
$T^{N}$ spite of recent advances in the pharmacokinetics and pharmacology of 1 digitalis glycosides intoxication with these drugs is still a common clinical problem and has been reported in as many as $20 \%$ of individuals receiving these medications. ${ }^{1)}$ The advent of radioimmunoassay technique enabled its use in the development of rapid, sensitive, specific, and convenient way of the routine clinical measurement of serum digitalis concentration. ${ }^{2}$ ) Since there is no effective drug available for treatment of digitalis toxicity, the mainstay of treatment consists of discontinuation of the drug until the excretory mechanisms dissipate the active components. Other measures such as administration of potassium chloride, diphenylhydantoin, sodium ethylenediamine tetra-acetic acid (EDTA), propranolol, and digoxin antibodies have all been advocated. ${ }^{31,4)}$ Agents such as activated charcoal, certain resins with high affinity for bile salts (Cholestyramine), ${ }^{51}$ Kaopectate, $\left.{ }^{6}\right)$ neomycin, ${ }^{71}$ drugs affecting gastrointestinal motility, ${ }^{8}$ ) and diphenylhydantoin have been reported to interfere with digoxin absorption, ${ }^{9}$ " however too few reports have yet been published to assess the magnitude and frequency of these effects in human subjects. Cholestyramine, an agent which binds digitalis molecule in the bowel and interrupts its enterohepatic circulation is effective in digitoxin toxixicity with $26 \%$ enterohepatic circulation, ${ }^{10}$ ) however, it does not significantly affect digoxin pharmacokinetics with an enterohepatic re-circulation of only $6.5 \% \cdot{ }^{11}$ It has recently been shown that intravenous administration of large dose of penicillamine lowers serum digoxin level in dogs. ${ }^{12}$ ) This study was undertaken to determine the efficacy of penicillamine on serum digoxin levels in digitalized patients.

\section{Materials and Methods}

Thirty-three patients (22 males and 11 females) in the age of 15-40 years who had congestive heart failure secondary to rheumatic valvular, ischemic or congenital disease and received daily maintenance dose of digoxin (Burroughs Welcome) were selected for this study. Informed consent was obtained in all individuals and each patient served as his own control. All patients had clinical and electrocardiographic evidences supporting optimal digitalization without any toxic effect. The patients were divided in 3 groups. Group I (10 pts) received daily oral maintenance digoxin at $6 \mathrm{AM}$ and had 4 SDMs (double antibody radioimmunoassay kit, New England Nuclear, Boston, Mass) at intervals of 2 hours (beginning at $8 \mathrm{AM}$ ) prior to and $2 \mathrm{hrs}$ after $1 \mathrm{Gm}$ of oral penicillamine. In order to exclude the interference of penicillamine with digoxin absorption Group II (13 pts) received daily maintenance digoxin orally at $10 \mathrm{AM}$ and SDMs were obtained $22 \mathrm{hrs}$ after their last oral doses of digoxin before and $6 \mathrm{hrs}$ after receiving $1 \mathrm{Gm}$ of penicillamine. For further confirmation of lowering effect of penicillamine on SDL regardless of the route of digoxin administration, Group III (10 pts) received $0.125-0.25 \mathrm{mg}$ maintenance digoxin intravenously for 5 days and had SDM similar to Group I. It is noteworthy that possibility of 
Table I. Methods of Digoxin and Penicillamine Therapy in 3 Groups of Patients

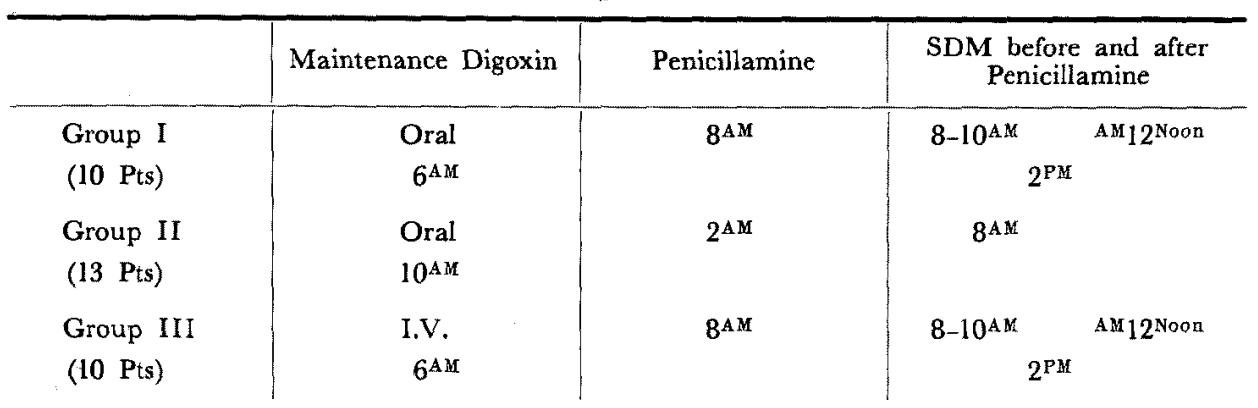

penicillamine interference with digoxin assay was excluded by adding various amounts of penicillamine to the tubes with predetermined digoxin concentration. Digoxin recovery was unaltered with and without addition of penicillamine. Table I summarizes the method.

\section{Results}

No patient exhibited any side effects or electrical instability following penicillamine therapy. The effect of penicillamine on serum digoxin levels in Group I patients is summarized in Table II. The mean SDL was reduced from $1.86 \pm 0.25 \mathrm{ng} / \mathrm{ml}$ to $1.62 \pm 0.22 \mathrm{ng} / \mathrm{ml} 2 \mathrm{hrs}$ following administration of penicillamine with statistical significance $(p<0.025)$. The lowering effect of penicillamine on SDL became increasingly more significant at 4 and $6 \mathrm{hrs}$ with values of $\mathrm{p}<0.005$ and $\mathrm{p}<0.001$, respectively.

Table III shows that mean serum digoxin level was lowered from $1.50 \pm$ $0.48 \mathrm{ng} / \mathrm{ml}$ to $1.16 \pm 0.51 \mathrm{ng} / \mathrm{ml}$ in 13 patients who received penicillamine $16 \mathrm{hrs}$ following their last maintenance oral digoxin. This effect is also statistically significant with $\mathrm{p}<0.05$.

The lowering effect of penicillamine on SDL in 10 patients who received digoxin intravenously is shown in Table IV. It is apparent that serum digoxin

Table II. Serum Digoxin Levels (ng/ml Mean \pm SD) in Group I before and after Administration of Penicillamine

\begin{tabular}{c|c|c|c}
\hline Time hrs & Before Penicillamine & After Penicillamine & Significance \\
\hline 0 & $1.96 \pm 0.31$ & $1.90 \pm 0.22$ & not significant \\
2 & $1.86 \pm 0.25$ & $1.62 \pm 0.22$ & $\mathrm{p}<0.025$ \\
4 & $1.80 \pm 0.17$ & $1.44 \pm 0.26$ & $\mathrm{p}<0.005$ \\
6 & $1.87 \pm 0.27$ & $1.14 \pm 0.24$ & $\mathrm{p}<0.001$
\end{tabular}


Table III. Serum Digoxin Levels (ng/ml Mean \pm SD) in Group II before and after Administration of Penicillamine

\begin{tabular}{c|c|c|c}
\hline Time hrs & Before Penicillamine & After Penicillamine & Significance \\
\hline 6 & $1.50 \pm 0.48$ & $1.16 \pm 0.51$ & $\mathrm{p}<0.05$
\end{tabular}

Table IV. Serum Digoxin Levels ( $\mathrm{ng} / \mathrm{ml}$ Mean \pm SD) in Group III before and after Administration of Penicillamine

\begin{tabular}{c|c|c|c}
\hline Time hrs & Before Penicillamine & After Penicillamine & Significance \\
\hline 0 & $1.77 \pm 0.37$ & $1.66 \pm 0.269$ & not significant \\
2 & $1.45 \pm 0.52$ & $1.288 \pm 0.34$ & not significant \\
4 & $1.36 \pm 0.50$ & $1.04 \pm 0.40$ & $p<0.001$ \\
6 & $1.46 \pm 0.69$ & $0.506 \pm 0.64$ & $p<0.005$
\end{tabular}

level was reduced insignificantly at $2 \mathrm{hrs}$, however it was significantly lowered at 4 and $6 \mathrm{hrs}$ after penicillamine administration with respective values of $\mathrm{p}<0.001$ and $\mathrm{p}<0.005$.

\section{Discussion}

Since the discovery by William Withering in 1785 digitalis preparations remain one of the most valuable drugs available for the treatment of heart failure. In spite of wide clinical use of digitalis glycosides, intoxication with these drugs continues to be one of the most common adverse drug reactions in clinical medicine. Digitalis intoxication has been reported from about $8 \%$ to as high as $35 \%$ in the hospitalized patients who had received cardiac glycosides. ${ }^{13}$ ) The symptoms related to gastrointestinal tract remain the most common reactions in digitalis toxicity. However, disturbances of cardiac rhythm have been observed as the first manifestation in $33 \%$ and overall incidences of cardiac arrhythmias and conduction abnormalities are estimated as high as $80 \%$ in those who have exhibited the toxic effects. ${ }^{1)}$

No single effective method for treatment of digitalis toxicity is clinically available. Although the application of digitalis antibodies in treatment of digitalis toxicity by Smith et al is promissing, ${ }^{14)}$ further investigations are warranted to prove the safety and efficacy of this technique.

Our study provides evidence that serum digoxin level can be significantly reduced by the use of penicillamine in man irrespective of the route of administration. None of our patients, with the dose used in this study, showed 
any adverse side effects of penicillamine and thus it can be used in individuals with digitalis toxicity.

Penicillamine is effective in the treatment of digitalis induced cardiac arrhythmia in dogs and lowers serum digoxin level in man. Therefore it seems reasonable to assume that penicillamine by altering the subcellular action or concentration of digitalis exerts it beneficial effect in digitalis toxicity. Thus it may be of value in the management of digitalis excess or toxicity in man.

The exact mechanism by which penicillamine lowers serum digoxin level is not yet known, however, digitalized animals receiving penicillamine have shown no increase in the total urinary output of free glycosides. ${ }^{12}$ ) Furthermore, penicillamine blocking effect on digoxin with $6.5 \%$ entrohepatic recirculation cannot explain the fall in serum digoxin level in penicillamine treated individuals. Whether digoxin is eliminated faster or sequestered in the noncirculating part of the body by penicillamine, a chelating agent is not known.

\section{REFERENGES}

1. Mason DT, Zelis R, Lee G et al: Current concepts and treatment of digitalis toxicity. Am J Cardiol 27: 546, 1971

2. Oliver GC, Parker BM, Brasfield DL, Parder CW: The measurement of digoxin in human serum by radioimmunoassay. J Clin Invest 47: 1035, 1968

3. Chung EK: Digitalis Intoxication. Excerpta Medica Foundation, Amsterdam, pp 165, 1969

4. Smith TW, Levine HJ (cd): Digitalis in Clinical Cardiovascular Physiology. Grune \& Stratton Inc, New York, p 33, 1976

5. Goldfinger SE, Heizer WD, Smith TW: Malabsorption of digoxin in malabsorption syndrome. Gastroenterology 58: 952, 1970 (abstr)

6. Marcus FI: Current concepts of digitalis therapy. Mod Concepts Cardiovasc Dis 45: 77,1976

7. Lindenbaum J, Maulitz RM, Saha JR et al: Impairment of digoxin absorption by neomycin. Clin Res 20: 410, 1972 (abstr)

8. Manninen V, Apajalahti A, Melin J et al: Altered absorption of digoxin in patients given propantheline and metoclopramide. Lancet 1 : 398,1973

9. Lahiri K, Ertel N: Mechanism of diphenylhydantoin induced decrease in serum digoxin levels. Clin Res 22: 32 IA, 1974 (abstr)

10. Okita GT: Species difference in duration of action of digitalis glycosides. Fed Proc 26: 1125, 1967

11. Doherty JE, Flanigan WJ, Murphy ML et al: Tritiated digoxin. XIV. Enterohepatic circulation, absorption and excretion studies in human volunteers. Circulation 42: 867, 1970

12. Ghani MF: The treatment of elevated serum digoxin level with penicillamine. An experimental study. J Lab Clin Med 84: 823, 1974

13. Smith TW: Digitalis toxicity. Epidemiology and clinical use of serum concentration measurements. Am J Med 58: 470, 1975

14. Smith TW, Haber E, Yeatman $L$ et al: Reversal of advanced digoxin intoxication with Fab fragment of digoxin-specific antibodies. New Eng J Med 294: 797, 1976 